\title{
臥位での室空間の印象評価と間仕切の大きさ・位置との関係に関する実験的研究 THE EXPERIMENTAL STUDY ON RELATION BETWEEN A PARTITION AND SPATIAL IMPRESSION FROM RECLINING POSTURES
}

\author{
橋本 雅好*, 彭 瑞 玟**, 西出和彦*** \\ Masayoshi HASHIMOTO, Jui-wen PENG and Kazuhiko NISHIDE
}

\begin{abstract}
The purpose of this study is to clarify the effect that the shape and the position of partition have on spatial impression from reclining postures. The various shape and position of partition panel is presented randomly. There are two types of subject's posture (i.e. reclining, standing), and two types of subject's position (i.e. parallel, sheer). Subjects are asked spatial impressions.

The results are summarized as following:

1).The evaluation of subjects regarding "comfortable","oppressive feeling","security of owned place" and "sightobstruction of partition panel" would be changed by the different posture in the examined area.

2).The important element of the evaluation of subjects was the relationship between the differrent eye-height by subject's posture and the partition-height.
\end{abstract}

Keywords: reclining postures, partition, subject's posture, subject's position, spatial impression 卧位、間仕切、被験者の姿勢、被験者の位置、室空間の印象評価

\section{1. 研究の背景・目的}

筆者らはこれまでに、室空間における臥位での容積の知覚や室空間 の印象評価といった空間認知特性に関して実験的に検証しねい 、卧位 での空間認知特性は立位と異なり、臥位特有の傾向を示すことを明ら かにした。これらの実験は室空間の形状に着目したものであり、実際 の室空間で見られるような家具や間仕切といった物理的要因の影響に ついては、検討していない。

例えば、実際の病室（多床室）などを見た場合に、間仕切を活用し た事例があることからも、間仕切と卧位での空間認知特性との関連性 を明らかにすることは重要であると考える。そこで本研究では、間仕 切の大きさや位置を変数とした実験をおこない、間仕切の大きさと位 置が、室空間の印象評洒に与える影響を、被験者の姿勢が臥位と立位 の場合を比較しながら、検証することを目的とする。

\section{2. 既往の関連研究}

間仕切に着目した研究は、国島章民ら (1989) 就 や森保洋之 (1995) 丈い)などが、縮尺模型を用いた評定実験によって、パーティションに よる空間分割の効果と圧迫感、開放感との関倸や空間の仕切り方と視 覚的な一体性・連続性との関係について検証した。これらの研究によ ると、窒内空間の快適性には、圧迫感と開放感が哚く関わっており、
それらはパーティションの立体角投射率に影響を受けるという結果 や、視覚的な一体性・連続性は、間仕切の横幅と高さ、開口部がある かないかなどのバランスで評価されるという結果を得た。

これらの間仕切に関する奏験的研究は、縮尺模型による実験が主で あり、実際の室空間レベル（実物大の実験空間）での実験は、ほとん ど見あたらなかった。そこで筆者らは、間仕切の大きさ・位置と人間 の空間認知特性や行動特性との関係について、実物大の実験空閒を用

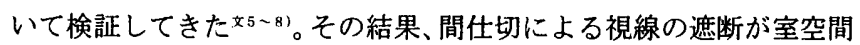
の印象評価や容積の知覚に影響を与え、また、同じ間仕切であって も、立位と座位とでは室空閒の印象評価が異なることなどを明らかに した。

以上のようなことから、室空間を仕切る役割をもつ間仕切の大きさ や位置は、その室空間に対する印象に大きな影響を与える重要な要因 であると考えられる。また、臥位が主な姿勢となる実際の病室におい てを、間仕切を用いた事例六（写真 1 、図 1）が見られることからも、 臥位と間仕切との関係を検討することは重要であると考える。

\section{3. 実験空間の設定}

実験空間の設定を図 2 に示す。実験空間は、大学の講義室を利用 し、白色（N9.5. 修正マンセル表色系）のダンボール箱を積んで壁面
* 平安女学院大学生活環境学部生活環境学科 講師・博士 (工学)

** 國立台北科技大學設計學院工業設計系 助理教授・博士 (工学)

*** 東京大学大学院工学系研究科建築学専攻 助教授 $\cdot$ 博士 (工学)
Lecturer, Dept. of Human Life and Environment, Faculty of Human Life and Environment, Heian Jogakuin (St. Agnes') University, Dr. Eng. Assistant Prof., Dept. of Industrial Design, Faculty of Design, National Taipei Univ. of Technology, Dr. Eng.

Assoc. Prof., Dept. of Archit., Graduate School of Eng., The Univ. of Tokyo, Dr. Eng. 
を作り、実物大の実験空間を設けた。実験空間の寸法は、床面を 5400 $\times 3600$ (単位 $; \mathrm{mm}$ 、以後略)、天井高を 2700 とした ${ }^{11}$ 。実験空間の 長辺の中央に間仕切を配置した。出入口は、被験者が 2 人同時に入室

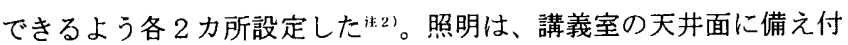
けのものを利用し、実験時の照度は、約 4001x であった。

\section{4. 間仕切の設定}

ここでは、図 3 に示すものを間仕切」と定義し、様々考えられる 間仕切の設定の中から、次の 3 つの条件にしたがって、図 3 に示す間 仕切型を選定した。

(1). 間仕切の高さの変化量は、450ピッチとし、間仕切の横幅の変化 量は: 900 ピッチとした（A 型、B 型、C 型)。

(2). 間仕切の位置が与える影響を検証するため、間仕切が中央にある 場合を設定した（B型と D 型の比較）。

(3). 実際の室空間（特に、多床室の病室）でよく見られる間仕切と似 た形状のものを設定した（E型）。

以上の条件と被験者の疲労、慣れの面を考慮して、間仕切の設定数

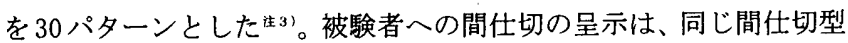
が続かないようランダムにおこなった。また、設定した間仕切は発泡 スチロール製（白色系：5Y9.5/1.0）で、厚さが 100 のものを使用し た。

\section{5．被験者の姿勢・位置・属性}

被験者の姿勢や位置の違いが、室空間の印象評価に与える影響を明 らかにするため、被験者の室空間を体験する姿勢は、図40ように、 臥位と立位の 2 種類を設定した。さらに、卧位については、ベッドの 位置を、間仕切に対して平行の場合と間仕切に対して垂直の場合の 2 種類を設定した。ここで設定した姿勢・位置で、す べての間仕切型に対して、実験をおこなったわけ ではなく、姿勢の違いによる影響や間仕切の位置 の違いによる影響を検証するために必要と考えら れる設定の実験をおこなった（表 1 参照）。

また、被験者は20名の男女 (身辰 : 平均 $=1647.8$ 、標準偏差=67.4) であり、建築・デザイン系の大 学生・大学院生とした

\section{6. 実験の方法（図 2 参照）}

被験者は、最初に実験の教示生5)を受けた後、2 人同時に室空間内に入り、指定された位置・姿勢 で、15秒間空間を体験する。その後外に出て、5

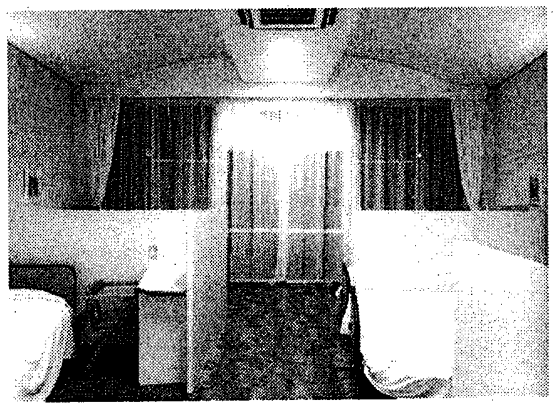

写真 1 . 間仕切を使った 4 床室丈91
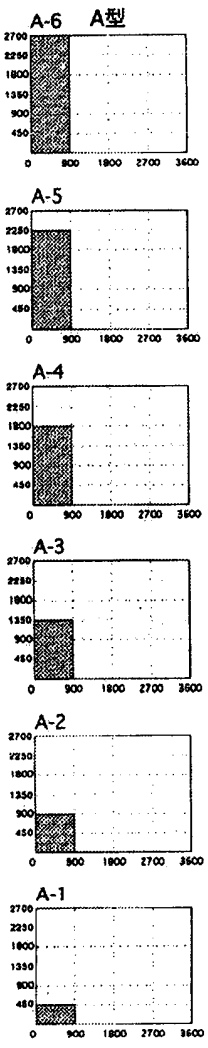

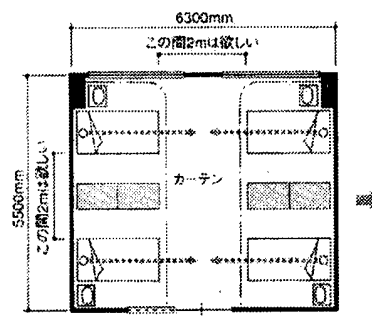

一般的 4 座害

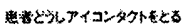

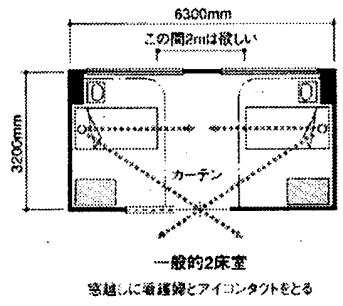

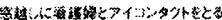

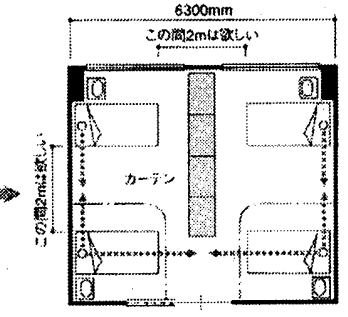

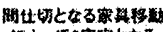

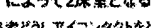

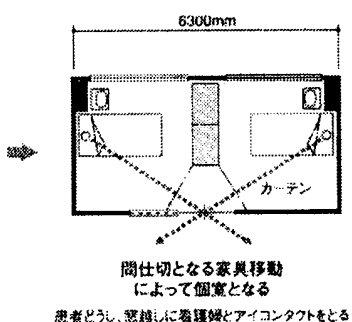

図 1，間仕切を使った病室のプランメッ!

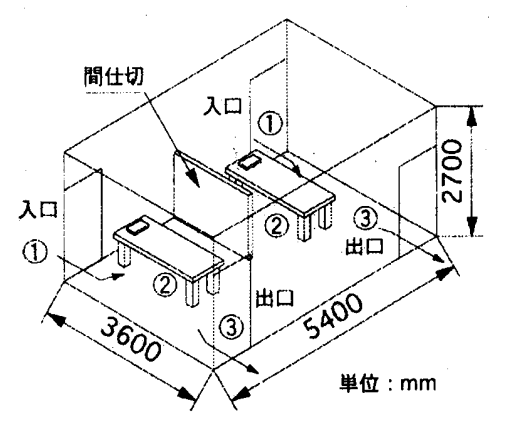

実験の手順

(1) 2 人同時に実験空間に入る (2)指定された位䞍と登勢て、 实駼空間を15秒間体駼する 3)実験空間を出て、5つの留問 項目に回答する

図 2.実験空間の設定と実験の手順
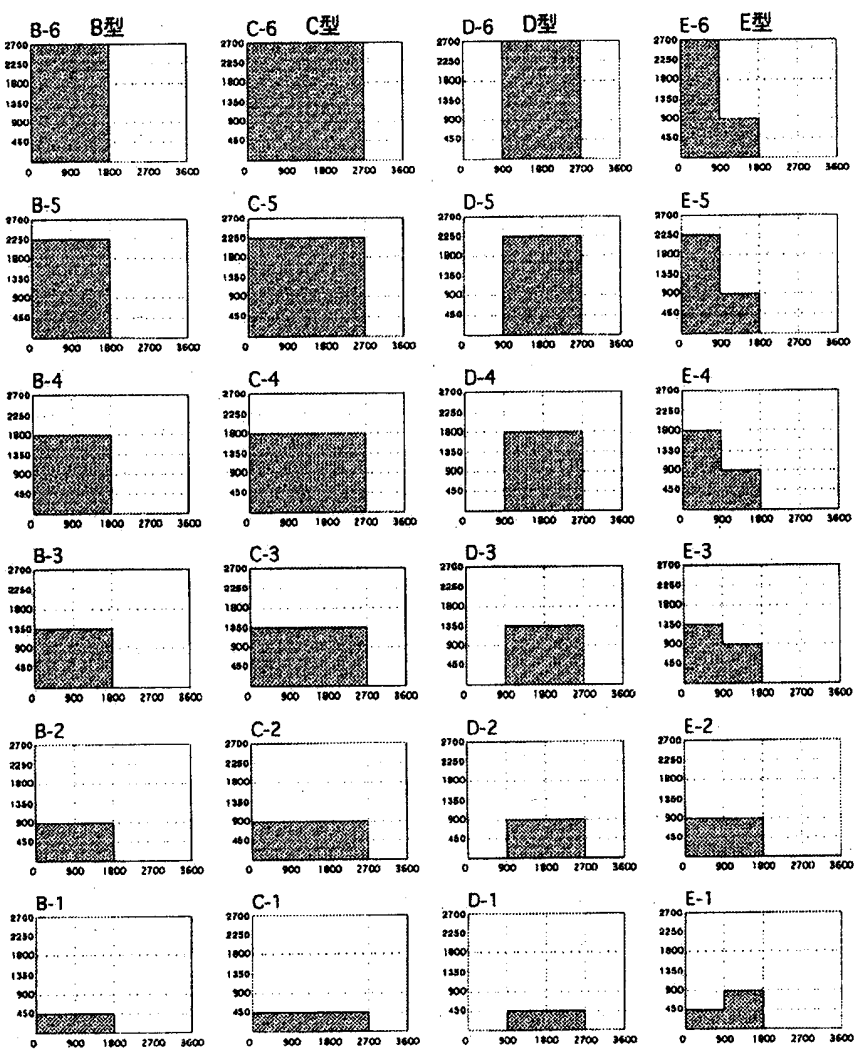

図 3．間仕切の設定 
つの質問項目に回答する。この一連の過程を各設定においてくり返し おこなう。

\section{質問項且}

(1).「分節感」年）．..「間仕切があることによって、空間をいくつと 感じるか」 $\rightarrow$ 回答項目 :「1．空間を 1 つと感じた、 2 . 空間を 2 つと感じた、 3 . 空間を（）つと感じた」

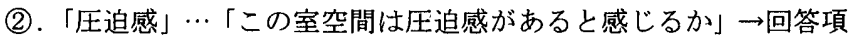
目：「1．圧迫感があると感じた、2．圧迫感がないと感じた」

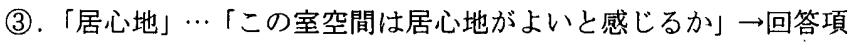
目：「1，居心地がよいと感じた、2，居心地が悪いと感じた」

(4).「自分の場所の確保」…間仕切があることによって、自分の場 所を確保できると感じるか」 $\rightarrow$ 回答項目：「1．自分の場所が確保 できる、2，自分の場所が確保できない」

(5).「目障り」‥「間仕切があることによって、目障りであると感じ るか」 $\rightarrow$ 回答項目：「1．目障り、2．目障りでない

\section{7. 分析の方法}

まず、室空間の印象評価に関する質問項目について、被験者の回答 が、選択肢のどれに有意に多いかに対する $x^{2}$ 検定と多重比較をおこ ない注7、被験者の各姿勢・位置ごとに間仕切の位置×間仕切の高さ の 2 要因分散分析と多重比較をおこなった ${ }^{\text {(8)。 }} \chi^{2}$ 検定、分散分析、 多重比較ともに、有意水準は $5 \%$ 以下とした。例えば、 $\chi^{2}$ 検定の 5 \%水準で有意差が見られた場合は、「 $\chi^{2}$ 検定で $p<0.05 」$ と表記する （特に表記のない場合は、有意差は見られなかったが、ある程度の傾 向が見られたということである)。

考察の段階では、実験終了後に、被験者に対しておこなったヒアリ ング（何を基準に評価したかなど）を参考にして分析をおこなった。

\section{8. 実験の結果}

室空間の印象評価の結果を図 $5 \sim 9$ に示寸。また、被験者の姿勢が 臥位で被験者の位置が間仕切に平行の場合を「臥位・平行」と、被験 者の姿勢が立位で被験者の位置が間仕切に平行の場合を「立位・平 行」と、被験者の姿勢が臥位で被験者の位置が間仕切に垂直の場合を 「臥位・垂直」と表記した。

\section{1 「分節感」の結果（図 $5 \cdot 1 \sim 3$ )}

全体的な傾向として、被験者の姿勢や位置に関わらず、間仕切の高

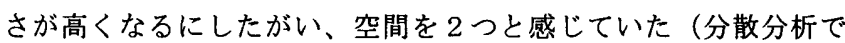
$\mathrm{p}<0.01)$ 。その中で、多くの場合、間仕切の高さが 1350 以上になる と、被験者の半数以上が、空間を 2 つ感じていた。

間仕切の位置の違いによる影響は、A型が他の型に比べ、間仕切の 高さが高い場合でも、空間を 1 つと感じていた（立位・平行では、分 散分析で $p<0.01)$ 。のことから、間仕切の横幅が 900 では、間仕切 の高さが高くなっても、空間を 2 つには感じに゙くいと考えられる。 8.2 「圧迫感」結果 (図6.1〜3)

全体的な傾向として、被験者の姿勢や位置に関わらず、間仕切の高 さが高くなるにしたがい、圧迫感があると感じていた（卧位・平行、 立位・平行では、分散分析で $p<0.01$ 、臥位・垂直では、分散分析で $p<0.05)$ 。

間仕切の位置の違いによる影響は、A型と E 型が他の型に比べ、間 仕切の高さが高くても、圧迫感を感じにくい傾向が見られた。

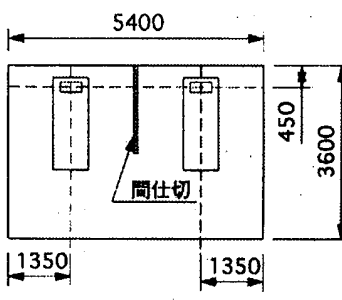

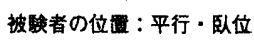

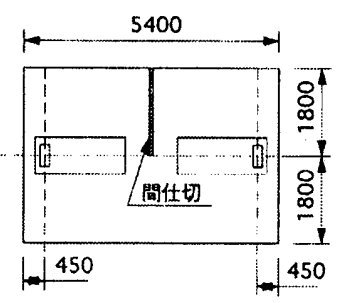

・被駼者の位監：垂淔・卧位

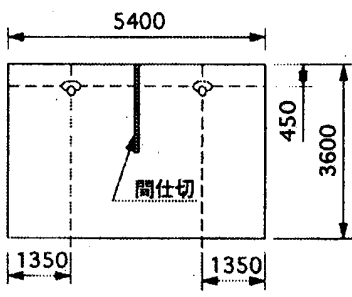

被梌者の位贯 : 平行・立位

単位: $\mathrm{mm}$
図 4．実験空間の体験方法

表 1. 実験をおこなった設定

\begin{tabular}{|c|c|c|c|c|c|}
\hline & A型 & B型 & C型 & D型 & E型 \\
\hline 臥位·平行 & $\mathrm{O}$ & 0 & $\mathrm{O}$ & 0 & 0 \\
\hline 立位 - 平行 & 0 & 0 & 0 & 0 & $x$ \\
\hline 卧位·垂直 & $x$ & 0 & $x$ & 0 & $x$ \\
\hline \multicolumn{3}{|c|}{ ర:実験をおこなったもの } & ：実騃 & なわ & たたの \\
\hline
\end{tabular}

8.3. [居心地」の結果 (図 $7 \cdot 1 \sim 3$ )

臥位・平行では、B型、C型、E型は、間仕切の高さが高くなるにし たがい、居心地がよいと感じていたが、A型は、間仕切の高さに関わ らず、居心地がよいと悪いとに評価が分かれ、D型は、間仕切の高さ に関わらず、居心地が悪いと感じていた（分散分析で $\mathrm{p}<0.01 ） 。$

立位・平行では、D型を除き、間仕切の高さが高くなるにしたがい、 居心地がよいと感じていた。一方、D型は、間仕切の高さに関わらず、 居心地が悪いと感じていた（分散分析で $p<0.01 ） 。$

臥位・垂直では、間仕切の高さに関わらず、B型が居心地が悪いと 感じていた被験者が多く、D型が居心地がよいと感じていた被験者が 多くいた（分散分析で $\mathrm{p}<0.01 ） 。$

8.4「自分の場所の確保」の結果（図 $8 \cdot 1 \sim 3$ )

臥位・平行では、居心地の評価と同様、 $\mathrm{B}$ 型、 $\mathrm{C}$ 型、 $\mathrm{E}$ 型は、間仕切 の高さが高くなるにしたがい、自分の場所を確保できる（以後、「確 保できる」と略す）と感じていたが、A型は、間仕切の高さに関わら ず、「確保できる」と「確保できないりとに評価が分かれ、D型は、間 仕切の高さに関わらず、「確保できないりと感じていた（間仕切の位 置の違いに対しては、分散分析で $\mathrm{p}<0.05)$ 。

立位・平行では、B型、C型は、間仕切の高さが高くなるにしたが い「確保できる」と感じていたが、A型は、間仕切の高さが低いと 「確保できない」と感じ、間仕切の高さが 1800 以上では、「確保でき る」と「確保できない」とに評価が分かれ、D型は、間仕切の高さに 関わらず、「確保できないりと感じていた（間仕切の位置の違いに対 しては、分散分析で $p<0.01$ 、間仕切の高さの違いに対しては、分散 分析で $p<0.05)$ 。

臥位・垂直では、D型は、間仕切の高さが 1350 以上になると、「確 保できる」と感じていたが、B型は、間仕切の高さに関わらず、「確 
保できる」と感じにくい傾向が見られた（間仕切の位置の違いに対し ては、分散分析で $\mathrm{p}(0.01)$ 。

\section{5 个目障り」の結果 (図 $9 \cdot 1 \sim 3$ )}

臥位・平行では、A型、C型、E型は、間仕切の高さに関わらず、目 障りでないと感じていたが、B型は、間仕切の高さが 900 以外では、 目障りでないと感じていたが、900では、目障りであると感じていた

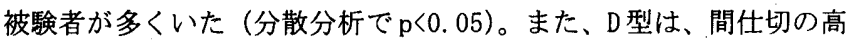

さが高くなるにしたがい、目障りであると感じていた（分散分析で $\mathrm{p}<0.05)$ 。

立位・平行では、D型を除き、間仕切の高さが高くなるにしたがい、 目障りでないと感じていたが、 $\mathrm{D}$ 型は、間仕切の高さに関わらず、目 障りであると感じていた（分散分析で $\mathrm{p}<0.01$ )。

臥位・垂直では、間仕切の高さに関わらず、B型が目障りであると 目障りでないとに評価が分かれ、D型が目障りでないと感じていた被
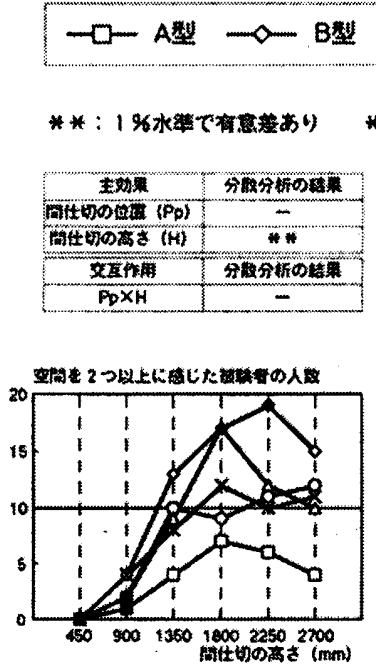

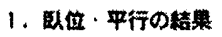
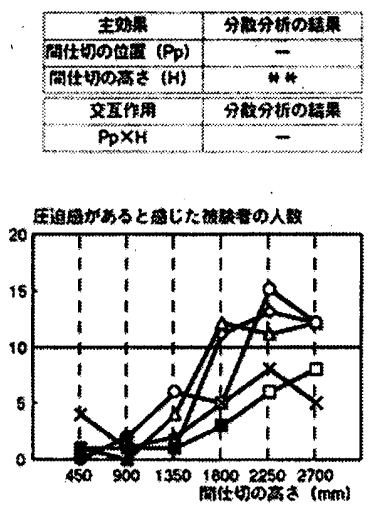

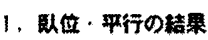
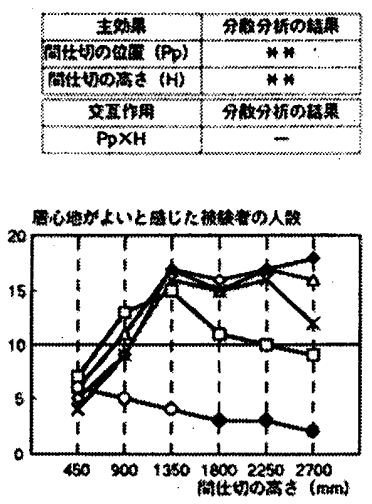

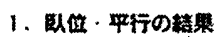
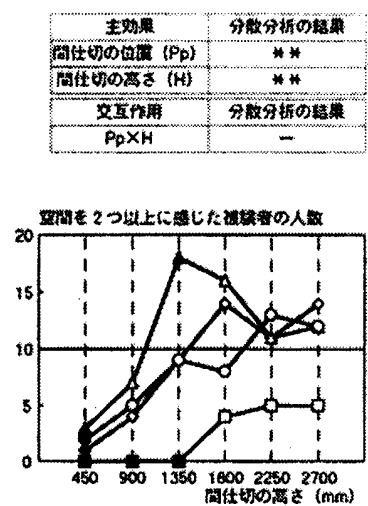

2. 立位・平行の结果

図 5. 分節感の評価の結果

\begin{tabular}{|c|c|}
\hline 主奻果 & 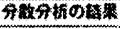 \\
\hline 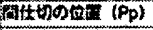 & - \\
\hline 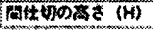 & ** \\
\hline 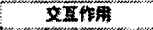 & 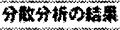 \\
\hline $\mathrm{Pp} \times \mathrm{H}$ & - \\
\hline
\end{tabular}

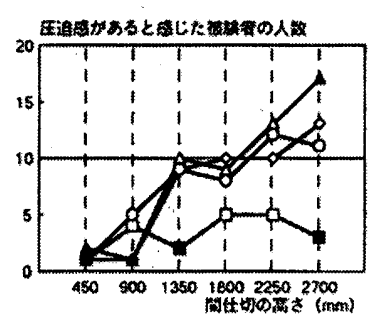

2. 立位 ·平行の哧果

図6. 圧迫感の評価の結果
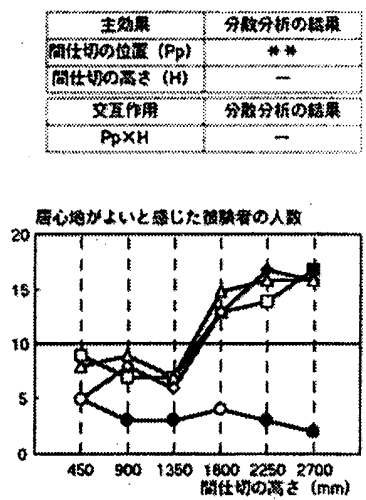

2. 立触一平行の結策

図 7. 居心地の評価の結果

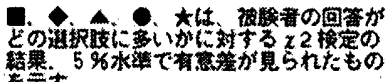

类然。
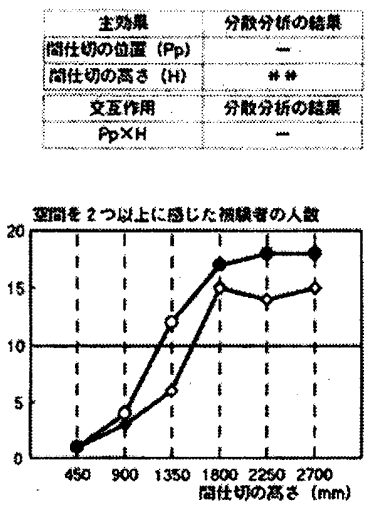

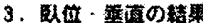
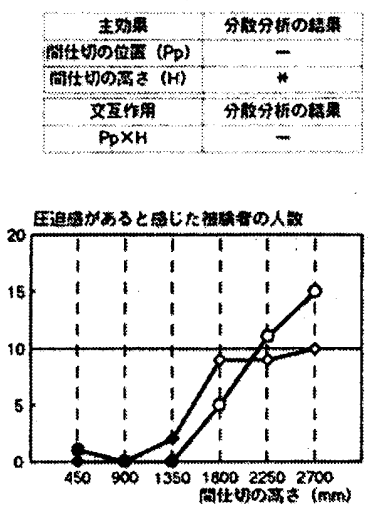

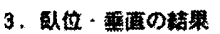
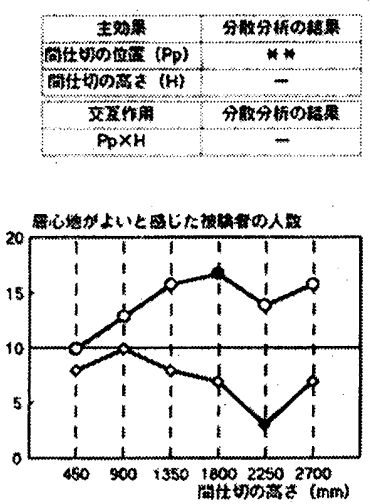

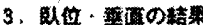



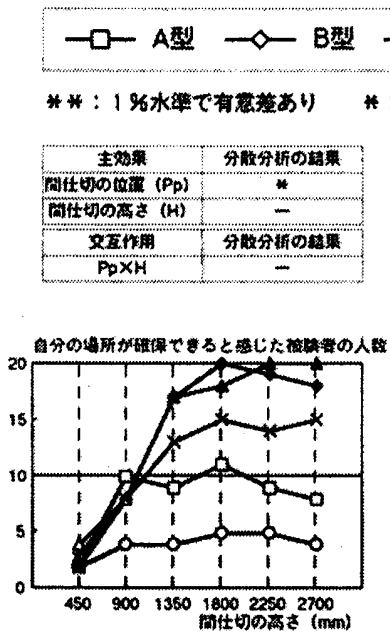

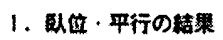
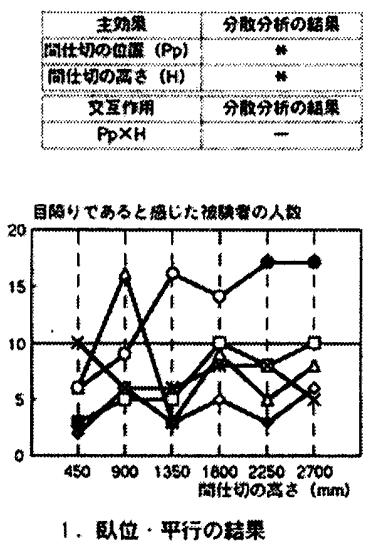

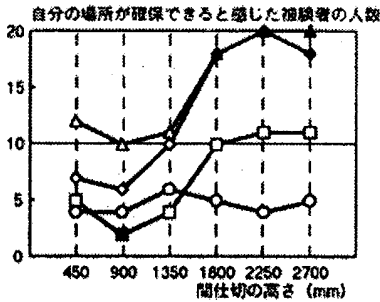

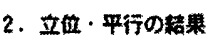

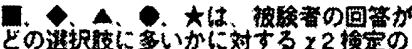

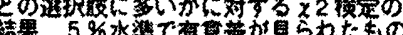
宗士.
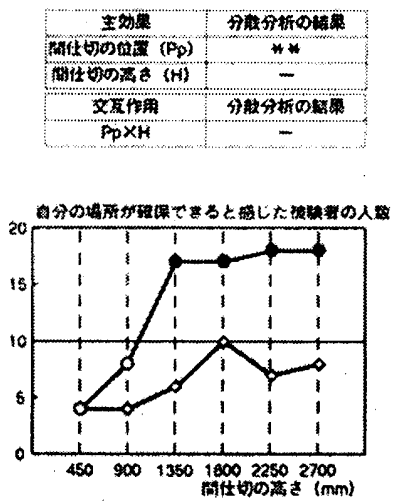

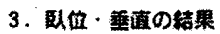

図 8. 自分の場所の確保の評価の結果
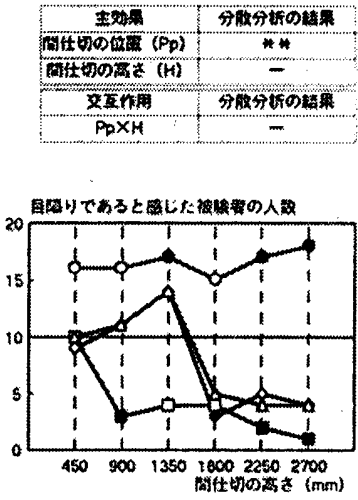

2. 立位 - 平行の转果
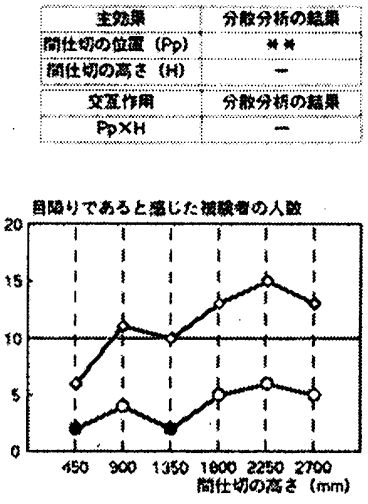

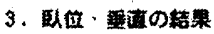

図 9. 目障りの評価の結果

験者が多くいた（分散分析で $\mathrm{p}<0.01 ） 。$

\section{9. 臥位での室空間の印象評価の傾向}

ここでは、各印象評価項目と間仕切の大きさや位置との関わりにつ いて、評価の手がかりとなる要因を検討しながら、卧位での室空間の 印象評価の傾向を考察する。

\section{1 「分節感」の評価}

臥位での分節感の評価では、間仕切の高さ $: 1350$ ・横偪 : 1800 以上 になると、空間を 1 つから 2 つへと感じる転換点法》が現れる傾向が あった（図 10・1）。一方、間仕切の位置やベッドの位置の違いの影 響はなく、同様の傾向であった。これらのことから、卧位での分節感 の評価は、間仕切の形状といった寸法が評価の重要な要因であり、間 仕切の位置、ベッドの位置の違いといった要因は評価には、影響を与 えないといえる。

\section{2 「「压迫感」の評価}

臥位での圧迫感の評価では、間仕切の高さ : 1800 ・横幅 : 900 以上 になると、圧迫感があると感じる転換点が現れる傾向があった（図 $10 \cdot 2)$ 。一方、間仕切の位置やベッドの位置の違いの影響はなく、 同様の傾向であった。これらのことから、臥位での圧迫感の評価は、 分節感と同様に、間仕切の形状といった寸法が評価の重要な要因であ り、間仕切の位㯰、ベッドの位置の違いといった要因は評価には、影
響を与えないといえる。

\section{3 居心地」の評価}

臥位での居心地の評価では、間仕切の高さ・横幅が 900 以上になる と、居心地がよいと感じる転換点が現れる傾向があった（図 10・3)。 また、間仕切の位置やベッドの位置の違いの影響も見られ、相手が見 えなくなるような設定を居心地がよいと感じる傾向があった（図 11)。これらのことから、臥位での居心地の評価は、間仕切の形状と いった寸法が評価の重要な要因であり、さらに、間仕切の位置、ベッ ドの位置の違いといった要因によっても、居心地の評価が異なるとい え、相手が見えるか否かが評価の重要な要因であるといえる。

\section{4 「自分の場所の確保」の評価}

臥位の自分の場所の確保の評価では、間仕切の高さ : 450 ・横幅 : 1800 以下の場合、確保できないと感じ、間仕切の高さ・横幅が 900 以 上では、確保できると感じる転換点が現れる傾向があった（図 10 ・ 4)。また、間仕切の位置やベッドの位置の違いの影響も見られ、相 手が見えなくなるような設定を確保できると感じる傾向があった(図 11)。これらのことから、臥位の自分の場所の確保の評価は、間仕切 の形状といった寸法が評価の重要な要因であり、さらに、間仕切や ベッドの位置の違いといった要因によっても、自分の場所の確保の評 価が異なるといえ、相手が見えるか否かが評価の重要な要因であると いえる。 


\section{5 「目障り」の評価}

臥位の目障りの評価では、間仕切の高さ : 900 ・横幅 : 2700 の設定 以外は、目障りでないと感じる転換点が現れる傾向があった（図 10 $5)$ 。また、間仕切の位置やベッドの位置の違いの影響も見られ、相 手が見えなくなるような設定を目障りでないと感じる傾向があった (図 11)。これらのことから、臥位の目障りの評価は、間仕切の形状 といった寸法が評価の重要な要因であり、さらに、間仕切やベッドの 位置の違いといった要因によっても、目障りの評価が異なるといえ、 間仕切の見え方が重要な要因であると考えられる。

\section{0. 姿勢の遣いが室空間の印象評価に与える影響}

ここでは、臥位と立位での実験結果を比較することによって、姿勢 の違いが室空間の印象評価に与える影響を考察し、卧位での室空間の 印象評価と間仕切の大きさ・位置との関連性を明らかにする。

「分節感」の評価は、姿勢の違いによる影響はあまり見られず、臥 位と立位ともに、同様の評価傾向を示していた。それ以外の評価項目 では、評価が変わる間仕切の寸法 (転換点) が、姿勢によって異なる 傾向が見られた。これは、姿勢による視線の高さの違い（臥位の視点 高: 845、立位の視点高 (平均)：1528）が影響を与えたと考えられる。 例えば、圧迫感があると感じ始める間仕切の高さは、臥位では $1800 、$ 立位では1350であり、居心地がよいと感じ始める間仕切の高さは、臥

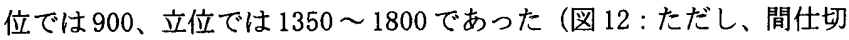
の横幅が 1800 以上の場合)。また、「目障り」の評価では、間仕切の 高さが、視線の高さ付近（卧位 : 900、立位 : 1350）の場合に、目障 りであると感じていた。これらのことから、臥位での室空間の印象評 価に対する間仕切が果たす役割としては、相手が見えるか否かといっ た人と人との関わりの部分で大きな要因となり、自分の領域を確保す るための重要な道具として活用できると考えられる。

以上のことから、臥位での室空間の印象評価は、特定の設定では、 臥位特有の評価傾向が見られたが、全体的な評価傾向については、立 位の場合とほぼ同様の評価傾向であるといえる。また、卧位、立位と もに、視線の高さ付近で評価が変わっていることから、姿勢による視 線の高さの違いと間仕切の高さとの関保が、評価の重要な要因である といえる。

\section{1. 多床室の病室での間仕切の活用}

ここでは本研究の成果を踏まえ、多床室の病室で活用する間仕切の 大きさ・位置を検討するき10)。

多床室の病室で間仕切を活用する場合は、ベッド上（卧位）では、 他の人たちの視覚的・物理的侵入を防ぎ、自分の領域を確保でき、病 室全体の印象（立位）では、居心地がよく、圧迫感がない状態がいい と考えられる。以上のことと本実験の成果から、居心地がよく自分の 場所が確保でき、圧迫感がなく、目障りでもない間仕切の大きさ・位 置を推測すると、相手が見えないような位置で目線の高さよりもやや 高い寸法（例えば、臥位・平行時で、間仕切の幅が 1800 、間仕切の 高さが臥位での視点の高さと立位での視点の高さの間の 1200 程度） が考えられる。

\section{謝辞}

実験空間の制作、及び、実験の被験者やスタッフとしては、千葉工
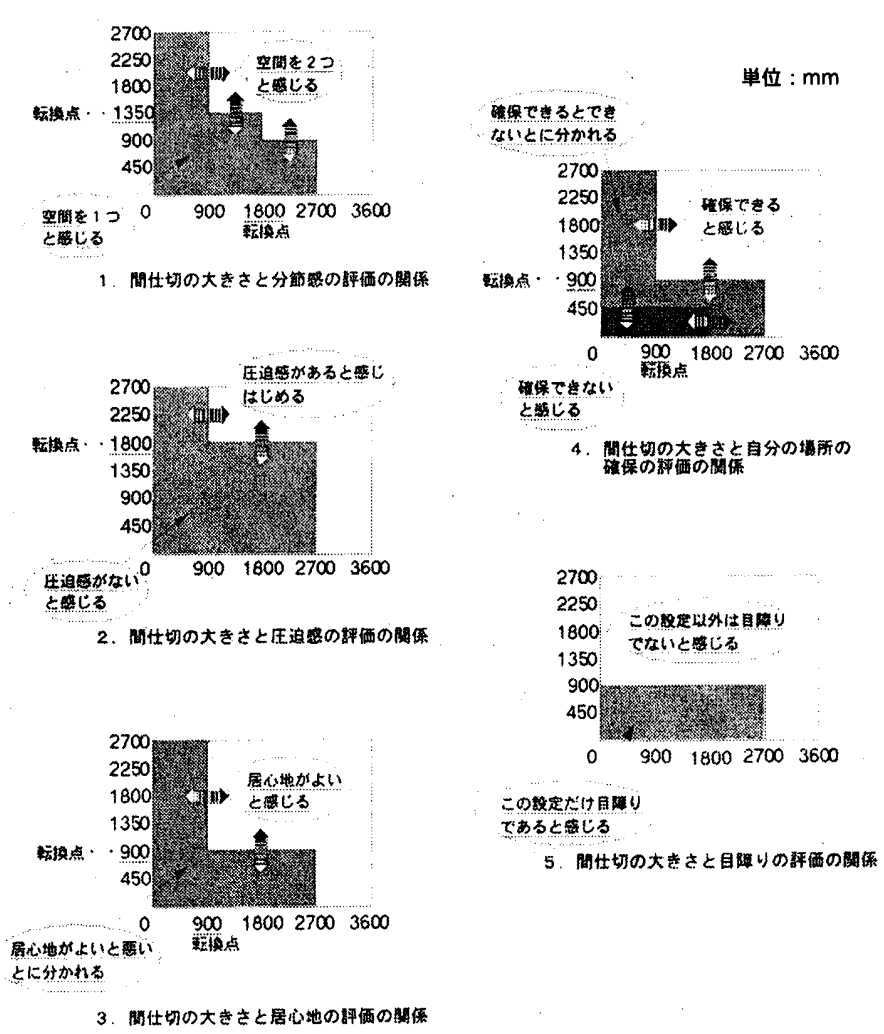

図 10. 臥位での室空閒の印象評価の傾向
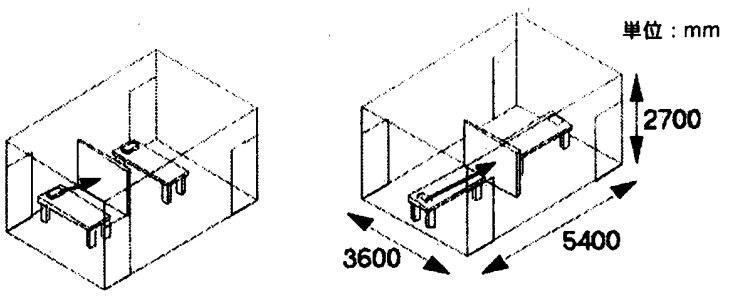

ロ相手が胃えなくなる間仕切の設定 居心地がよい、自分の場所を確保できる、目障りでない
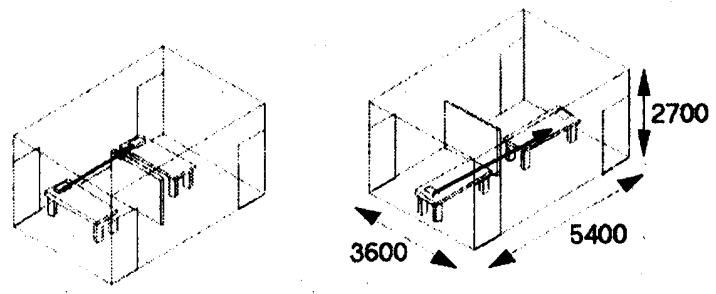

\section{ロ相手が見える間仕切の㱽定 居心地が琶い、自分の䭪所を確保できない、目障り}

図 11. 臥位での室空間の印象評価と間仕切の位置との関係

業大学と東京大学の学生・院生のご協力を得た。ここに記して関係者 の方々にお礼を申し上げます。

注

1）実験空間の床面の大きさを決定する際、まず、人間が体験する空空間とし て、実際の住宅などでよく見られる4.5盢 $(2700 \times 2700) 、 6$ 盢 $(2700 \times 3600) 、$ 8 畺 $(3600 \times 3600)$ の 3 つに注目した。また、本研究では、問仕切の設定数 を多くすることを重要視したため、室空間の床面の大きさは一定とした。 よって、先に挙げた 3 寸法から、一辺が 2700 と 3600 ともに表現できる 6 畳 


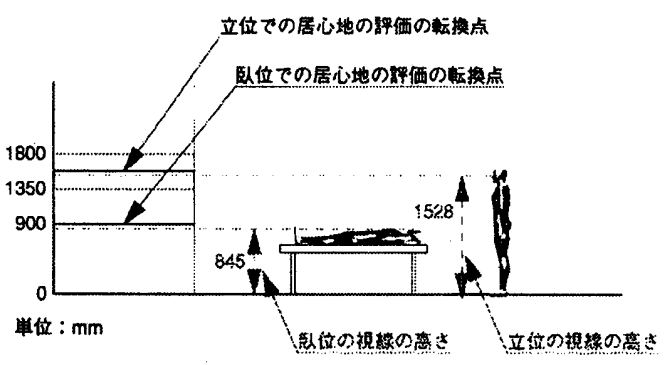

※居心地の評価の転換点は、

各姿勢の視線の高さ付近である

図 12. 姿勢の違いが室空間の印象評価に与える影響

$(2700 \times 3600)$ を取り上げ、室空間の床面の大きさをこの空間を 2 つ並べた $5400 \times 3600$ とした。天井高は、実験空間の制約、間仕切の設定条件と今後の 住宅計画での可能性を考え 2700 とした。

2） 2 人の被験者が同時に実験空間に入るのは、室空間の印象評価には、間仕 切の大きさや位圈が影響を与えると同時に、人と人との相互作用が影響を与 えると思われるため、人と人との関わりを含めた間仕切の大きさ・位㯰の影 響を検証するために、2人の被験者が同時に入室することとした。

3 ) 間仕切の設定上、B-2 と E-2 は同じ形状となるため、実験では 1 パターンの みをおこない、そのデータをぞれぞれのデータとした。そのため、実際に実 験でおこなった設定数は 29 パターンである。

4）実験をおこなった日程は 1999 年 6 月 28 日、7 月 $3 、 4$ 日の 3 日間である。 実験は、午前 10 時から午後 3 時までおこなった。午前 11 時 30 分から 1 時間 を昼食の時間とした。また、被験者は実験空間の設定やべッドの移動などの 待ち時閒では、本を読んだり、軽い飲食などでくつろいだ状態であった。

5 ）実験をおこなう際、被験者に以下の教示文を呈示した。 「これから、室空間における間仕切が与える印象評価実験をおこないます。 この実験では、基本的に皆さまにこちらが指示した姿勢（臥位、立位）で間 仕切と室空間の印象について評価していただきます。臥位では、ベッド上に 仰向けに寝ていただきます。この際、頭は枕から雄さない程度動かしても構 いませんが、上体は起こさないようにして室空間を体験してください。ま た、立位では、こちらが指定した位置に立ち、頭は動かしても構いませんが、 上体は動かさないようにして室空間を体験してください。

次に、実験の手順について説明します。まず、こちらが指定した入口から 室空間内に入っていただき、こちらが指定した姿勢で空空間を体験してくだ さい。一定の時間が経ちましたら合図をしますので、室空間を出て、こちら のテーブルで回答用紙に回答していただきます。この行程をくり返しおこな います。回答方法についてですが、質問は全部で 5 項目あります。各質問の 選択肢のいずれか 1 つに○を付けてください。

これは皆さまの空間感覚の能力を試すためのものではありませんので、直感 的な感覚を素直に答えてください。なお、被験者どうしで、実験空間や回答 についてお話をされますと、実験結果に影響を及ぼす可能性がありますの で、絶対に相談などしないでください。実験に関して何かわからない点や不 都合がある場合は、実験者にお話ください。」

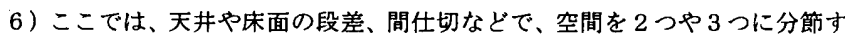
る感覚を分節感と定義した。

7 ）被験者の回答を選択肢ごとに集計し、帰無仮説 Ho「被験者の回答の分布に は偏りがない」のもと、 $\chi^{2}$ 検定をおこなった。また、帰無仮説H0が育却さ れ「回答の分布には偏りがある」となったものに対して、さらに、どの回答 が他の回答よりも有意に多いかの多重比較（ライアン法）を抏こなった。

$x^{2}$ 検定、多重比較の方法については、参考文献 10）を参照した。

8 ) 間仕切の位固、間仕切の高さのそれぞれの要因について、㷌無仮説 Ho「そ れぞれの要因について被験者の回答の分布には偏りがないりもと、2 要因 分散分析をおこなった。また、帰無仮説 $\mathrm{H} 0$ が赍却され「回答の分布には偏 りがある」となったものに対して、さらに、どの要因の回答が他の回答より も有意に多いかの多重比較（ライアン法）をおこなった。2 要因分散分析、
多重比較の方法については、参考文献 10）を参照した。

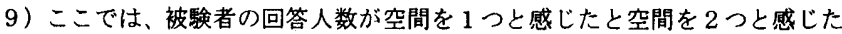
とに半々に分かれた地点 (評価が変わる間仕切の寸法)を転換点と定義した。 同様に、他の評価項目も被験者の回答人数が半々に分かれた地点を転換点と 定義した。

10）本実験では、2 床室の設定でおこなっているが、実際の病室では、他にも 4 床室や 6 休室といった多床室が多い。それらの状況では、本実験のベッド の位膡の平行と垂直の組み合わせで考えることができると思われる。

\section{考文献}

1) 須田䢐史、橋本雅好ほか：室空間における距離・容積の知賞に関する実験 的研究 臥位での空間の知覚特性に関する研究、日本建築学会計画系論文集 第 499 号、pp. $89 \sim 96 、 1997.9$

2 ) 橋本雅好、西出和彦ほか：段差天井と容積の知覚・室空間の印象評価との 関係に関する実験的研究、日本建築学会計画系論文集 第540号、pp. 167〜 173、2001.2

3) 国島章民、内田茂ほか：パーティションの視覚的効果に関する研究、日本 建築学会大会学術講演梗概集、pp. 127-128、1989

4 ) 森保洋之 : 室内空間の視知賞的把握に関する研究一住宅の公的空間モデル とその視知覚イメージについて一、日本インテリア学会論文報告集 5 号、 PP. 1-6、1995. 3

5) PENG Jui-wen、橋本雅好ほか: 間仕切りの大きさ・位置と空間の使い分け、 印象評価の関係に関する基礎的実験、日本インテリア学会論文報告集 9 号、 pp. $39 \sim 45,1999.3$

6) PENG Jui-wen、橋本雅好ほか：室空間体験者の位膡・姿勢の違いが与える 影響 間仕切りの大きさ・位膡と空間の使い分け、印象評価の関係に関する 基礎的実験 その 2、日本インテリア学会論文報告集 10 号、pp. 25〜31、 2000.3

7) PENG Jui-wen、橋本雅好ほか: 間仕切が体験者の居場所に与える影響に関 する基礎実験 室空間における間仕切に関する研究 その 1 、日本建築学会 計画系論文集 第 535 号、pp. $131 \sim 137 、 2000.9$

8 ) PENG Jui-wen、橋本雅好ほか: 間仕切の大きさ・位圈と容樌の知覚との関 係に関する実験的研究、日本インテリア学会論文報告集 12 号、pp. 15 20、2002. 3

9) 日経メディカル開発編 : 安らぎの医療環境を求めて 病医院・施設に必要 な“瘱しの環境”づくり、日経メディカル開発、1997

10）森 敏昭、吉田寿夫 : 心理学のためのデータ解析テクニカルブック、北大 路書房、pp. 94-175、pp. 181-202、1990

(2003年10月 9 日原稿受理, 2004 年 1 月 9 日採用決定 